\title{
The Meaning and Implications of Ruth 4:5: A Grammatical, Socio-cultural and Juridical Investigation ${ }^{*}$
}

\author{
Milda de VAal-Stanton (University of Pretoria)
}

ABSTRACT

Uncertainty about the meaning of the problematic word compilation ומאת in its specific context in Ruth 4:5 creates a lack of clarity on the events which take place in Ruth 4. Such lack of clarity is reflected in the diversity of ancient and modern translations of this verse. It is uncertain whether the Moabite immigrant Ruth is described as also selling the land or whether she is merely seen as part of the sale transaction. The traditional view implies that a levirate marriage is involved in the narrative of this chapter. This interpretation creates multiple juridical problems. This article proposes that a usufruct is sold rather than land. Understanding and applying this legal concept can correct the misunderstanding of the verse. The problem is approached through a syntactical and grammatical analysis and justified in terms of the ideology in the book of Ruth. It is suggested that Ruth 4:5 should be rendered with, "The day you acquire the (right/usufruct in respect of) the field from the hand of Naomi and from (the hand of) Ruth, the Moabite woman, the wife of the deceased, you (also) acquire (her) in order to maintain the name of the deceased over his inheritance."

KEYWORDS: Ruth 4:5, women's inheritance rights, usufruct, redemption, levirate marriage

\section{A THE GRAMMATICAL PROBLEM OF RUTH 4:5 AND POSSIBLE SOLUTIONS}

Ruth 4:5

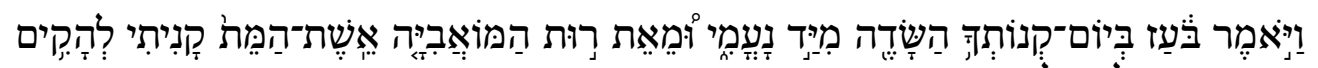

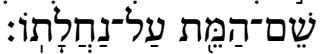

Traditionally, translations of this verse resulted in the following prevailing interpretations:

\footnotetext{
* Article submitted: 23 March 2015; accepted: 22 June 2015. To cite: Milda de Vaal-Stanton, "The Meaning and Implications of Ruth 4:5: A Grammatical, Sociocultural and Juridical Investigation," Old Testament Essays 28 no. 3 (2015): 674-693. DOI: http://dx.doi.org/10.17159/2312-3621/2015/v28n3a7
} 
(i) When you acquire the field from the hand of Naomi, you acquire (it) from Ruth, the Moabitess, the wife of the deceased (KJV, NKJV).

(ii) When you acquire the field from the hand of Naomi and from Ruth the Moabitess, you acquire the wife of the deceased (JPS, NJPS, MIV, The Vulgate, LXX).

(iii) When you acquire the field from the hand of Naomi, you also acquire Ruth the Moabitess, the wife of the deceased (NASB, NCV, TEV, RSV, NLT).

(iv) When you acquire the field from the hand of Naomi, then I acquire Ruth, the Moabitess, the wife of the deceased (REB, NET Translator's notes). sibilities:

These translation interpretations can be reduced to three translation pos-

(i) Naomi and Ruth sell the land;

(ii) Naomi and Ruth sell the land and Ruth must be married off;

(iii) Naomi sells the land and Ruth must be married off.

Another possibility will be explored which underlies the author's proposed interpretation and which might lead to a slightly different translation:

(iv) Naomi (or Naomi and Ruth) sell a right in respect of land, regardless whether Ruth gets married to the purchaser/speaker or not.

At this stage it is not clear at all to whom Ruth must be married.

The controversy mainly pivots around the following two interpretations:

(i) If you buy the land from the hand of Naomi, you acquire it also from Ruth, the Moabitess.

(ii) When you buy the land from the hand of Naomi, you also acquire Ruth the Moabitess.

It is noteworthy to point out that syntactically another קנה is lacking in the sentence. This missing verb would be the one requiring the object and not the last קנית.

Beattie $^{1}$ mentions only two difficulties found in the text on grammatical level which are the main sources of the confusion:

1 Derek R. G. Beattie, "The Book of Ruth as Evidence for Israelite Legal Practice," VT 24 (1974): 251-267, 236. 
First, there is the form, which, it is generally agreed, must be corrupt and by general consent of the commentators should be emended in such a way as to make the word "Ruth" the direct object of the verb that follows: ומאת רות.

The second and more significant phenomenon is that the verb in the second part of the verse has a Kethib and Qere form קניתי but this is vocalized so as to read קנית.

Beattie does not attempt to consider any other object than "Ruth" for the קנה in the sentence, neither does he recognise that a second (invisible) קנה last can be read into the sentence. It is also arguable whether the Kethib-Qere variation which is encountered in the verse offers the more important and problematic part of the translation, as workable solutions had been given by translators.

Following the translation of the Vulgate, Gow ${ }^{2}$ is not in favour of an "emendation" of the compilation ומאת רות because he regards the Vulgate translation as relatively "free." Neither does he believe that the compilation is "corrupted," but recognises that it may be ambivalent (in search of an object for קנית, while the search is in fact for an object for the second "invisible" קנה ", a viewpoint which is supported in this article.

\section{B GRAMMATICAL, MORPHOLOGICAL AND CONTEXTUAL ANALYSIS}

1. ומאת

(i) The compilation consists of $v a v$ copulative plus preposition (from/out of) plus deictic object marker את with replacement function" ("that") replacing "the hand" (of Ruth). ${ }^{5}$

2 Murray D. Gow, The Book of Ruth, its Structure, Theme and Purpose (Leicester: Apollos, 1992), 161.

See Emil Kautsch, Gesenius' Hebrew Grammar, (trans. A. E. Cowley, Oxford: Clarendon, 1978), 364, 117d, for examples where the foregoing object is not repeated as it was already mentioned in order to avoid repetition. It is presupposed that the reader bears knowledge of the object that is at stake. In this specific case, the object is the one that is unclear or unknown. See also 117 footnote 4 . In continuing footnote 3 on p. 363, the replacement value of is pointed out, as if the deictic pronoun had lost its force. It can be translated by ipsum (Lat.) dasselbe (Ger.) or same (Eng.). In my opinion, this rendering can resemble את in its capacity as so-called subject marker, because of the loss of meaning of the replaced word, and because of the importance of the meaning thereof.

4 Bruce Waltke and Michael O'Connor, An Introduction to Biblical Hebrew Syntax (Wynona Lake: Eisenbrauns, 1990), 307; 17.2b, classifies $-\boldsymbol{N}^{-}$in its capacity as object particle, as a deictic word which tends to be demonstrative."

5 Following the foregoing מיד in. 
Translation (i): and (buy it) from/out of that ("the hand") of Ruth.

This translation suggestion equals the one proposed in (1) as far as קניתך אתה מאת רות meaning is concerned: you (acquire) it from Ruth would be

It is clear from this translation that את will have to serve two purposes namely that of object marker replacing "the land" as well as that of preposition "from." In this case "Ruth" would be the indirect object. In my opinion this is exactly what is happening here.

It also equals the first part of translation suggestion (2). The part and from Ruth is but a simplified version of and from that (the hand) of Ruth, in which "the hand" would be the indirect object, repetition of which is regarded unnecessary. It would have been written: ומאת יד רות. In this case את will also not be an object marker, but only a preposition "from.", The possibility of rendering the whole clause "the wife of the deceased" as object for the (invisible) second קנה in the sentence will have to be analysed and justified syntactically, but will not be considered here.

(ii) The compilation can also consist of vav copulative plus conjunction word גת pointing to "Ruth" as direct object, following the translation of the Vulgate: Ruth quoque Moabiditem . . . debes accipere. ${ }^{8}$

Translation: and also Ruth. ${ }^{9}$

This translation resembles translation proposition (3), but the following should be noted:

The translation implies the acquisition/purchasing (not necessarily marriage to) of Ruth. For purposes of this article, it is important to ascertain whether a marriage is implied in the sentence. It is also relevant for purposes of

6 See Phil J. Botha, "Answers Disguised as Questions: Rhetoric and Reasoning in Psalm 24," OTE 22 (2009): 538, where a discussion of Ps 24:5 provides a translation of מאת ("out of" or "away from").The author's translation of the compilation consists of a contraction between the two prepositions מת and.

7 See also Kautsch's discussion (Kautsch, Gesenius' Hebrew Grammar, 364) of the

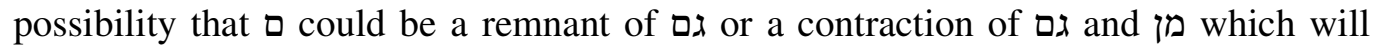
result in: "and also from the hand of" or "and also Ruth." In both cases the function of ג will be merely emphasis whereas the copulative particle i provides not only for the conjunction but also for the addition.

8 See also Gow, "Ruth, Quoque a Coquette," 303.

9 מ being a remnant of גalso," although Gow, "Ruth, Quoque a Coquette," 303, offers a proposition originating from the seventeenth century to delete the (which means that it is enclictic) and read: רות ואת. 
this article to ascertain whether it would imply a levirate marriage. ${ }^{10}$ Davies $^{11}$ draws the conclusion that it can only be the levirate marriage which could provide the waterproof legal tool for the provision of the widow of the deceased, because only along this way would she be able to "inherit" his "estate." 12 This statement can be proved lacking during the course of this article. A marriage does follow later on (in Ruth 4:9b-10a), but it is never stated that it is a levirate marriage.

It does not seem as if the last קנה in the sentence is in fact the verb which requires a direct object. This instance appears problematic in the text because of the first person singular rendering, although the object seems to be agreed upon: "Ruth." The question would be to ascertain whether a Kethib or Qere rendering would be preferable.

The textual criticism in BHS suggests the Latin Vulgate version of 1922: quo que, which will merely be translated as "also that" but does not suggest a direct object for the second (omitted/implied) קנה in the sentence.

It should also be noted that if regarded as an object marker, the maqqeph is lacking and the compilation results in ${ }^{-}$followed by no object. If "also from the hand of" is meant, "hand" will only be the indirect object and only replace the foregoing "land" ment particle.

(iii) The compilation can also consist of vav copulative plus conjunction word את plus object marker pointing to a missing object (for the second but omitted קנה) "hand," alternatively: deictic object particle replacing "hand of" to avoid repetition, whereas it had already appeared in the sentence.

Translation: and you will also (acquire) the hand of Ruth.

10 Eryl Davies, "Inheritance Rights and the Ancient Hebrew Levirate Marriage: Part 1," VT 31 (1981): 138-144, 139 offers a complete discussion of the origin and meaning of the levirate marriage.

11 Davies, "Inheritance Rights," 139.

12 Although Davies, "Inheritance Rights," 139, yields that this custom differed from the phenomenon found amongst neighbouring nations (Hittites, Assyrians and the people at Ugarit), he does not draw a clear distinction.

13 Note at this stage that I prefer utilisation of "land" as in fixed property to "field," to emphasise the legal concept of ownership which is in question in the pericope. "Field" can also mean "savannah" or imply a country-like scenery which is of course highly functional in order to create atmosphere and images of the countryside which form the backdrop activities for the narrative. It can also replace any word referring to a place where agricultural activities take place. 
In this case the translation will be of course figurative or idiomatic and will imply a marriage (not necessarily a levirate one) to Ruth. Whether this idiomatic expression existed in ancient Hebrew will have to be put to the test. Gow ${ }^{14}$ makes the statement that יד does indeed have an idiomatic application, in that it is used figuratively for economic possession or control, a fact that cannot be denied with reference to a man's marriage to a woman in ancient terms.

Also missing from the compilation מאת followed by Ruth, is the rendering of the construct state which is clearly needed in a phrase like: from the hand of. The missing object (for instance "hand") should be in the construct state.

\section{2. קניתי}

קנה Qal perfect 1 masculine singular of

Translation: "I bought."

Köhler and Baumgartner ${ }^{15}$ render this form as a perfect. Prinsloo ${ }^{16}$ and Loader ${ }^{17}$ both remark that the perfect tense is utilised here, as if Naomi had already sold the land, although both are convinced that this could not have been the intention. It is a well-known grammatical fact that the Hebrew perfect and imperfect tenses could alternate in ancient narrative literature, without necessarily affecting the meaning.

The BHS text-critical apparatus reads as follows, and can be found useful in making the ultimate choice: A few Hebrew texts have (Q) קנתה but it was written as (K) קנה fortasse.

The majority of translations make the emendation in order to make sense by utilising a second person singular form of the verb. Emendation of the verse on syntactical rather than morphological level can be explored. This will make the emendation of the word unnecessary, and provide a fresh, but sensible interpretation: you shall also acquire Ruth, (in the same way) as should I acquire her (subjunctive mood) and not: (because) I have already acquired her $^{18}$ (perfect). It should be clear that the emendation also lies on a syntactical level.

14 Gow, "Ruth, Quoque a Coquette," 303.

15 HALOT 8423.

16 Willem S. Prinsloo, Die Boek Rut (Kaapstad: N.G. Kerkuitgewers, 1982), 83.

17 James A. Loader, Ruth: Een practische Bijbelverklaring (TT; Kampen: Kok, 1994), 79.

18 As some translators prefer to believe, meaning that Boaz had already consummated his relationship with Ruth. See Gow, "Ruth, Quoque a Coquette," 304-305; Jack M. Sasson, Ruth: A New Translation with a Philological Commentary and a 
There is no real consensus on the content and meaning of this last קנה in the sentence. In the majority of translations, acquire is rendered, with the implied (although not explicit) meaning of marry. ${ }^{19}$ The core meaning of this stem had been rendered in at least one instance: the Jerusalem Bible, namely "then you also buy... Ruth."

Ruth 4:3 contains the object of the sale (the first קנה in v. 5), namely . Finding the exact semantic content thereof is important in order to find solutions to the questions surrounding the sale and other events in the pericope.

\section{3. חלקת}

Noun, feminine singular construct state of חלקה.

Translation: Part of; (ii) Cut off piece of; (iii) Share in/of. ${ }^{20}$

The noun is in the construct state, which precedes the (implied) genitive of the noun which follows, namely השדה. This observation is significant in that the sentence cannot be understood as if an entire or undivided entity is being sold. A ... (something) thereof is at stake.

It is true that idiomatically "a piece of land" could be a euphemistic reference to an entire farm in modern day language, but it cannot be ascertained without doubt that this expression existed in Ancient Hebrew.

If it can be found that the object of the sale is "a right in respect of" land and not land itself, the content of this right has to be investigated. A significant usage of "share in the land of" can be found in the German Luther Bibel. A share does not imply bare dominium, but a right, which is something less than ownership. If "cut-off piece" is to be understood, to whom does the other subdivisions belong? There is no indication in the text. It can, however, be understood figuratively to mean "a lesser right."

Formalist-Folklorist Interpretation (Sheffield: JJSOT Press, 1989), 119; Beattie, "Book of Ruth," 263.

19 Is there a big difference between "acquiring" and "marrying" a woman in ancient terms? "Marriage" did not include any paperwork or legal requirements like today. The procedure consisted of prior family negotiations, celebrations and the couple entering a tent and coming out of it the next day. In Hos 2:2 לקח is translated by "to take a wife" and in Hos 1:3 by "marry." See also the translation of the same word in Gen 4:19 and Gen 6:2 as well as Cornelis van Leeuwen, Hosea (POut; Nijkerk: Callenbach, 1968), 76 and Roland de Vaux, Hoe het Oude Israel Leefde (Utrecht: J. J. Romen, 1962), 73.

20 Although Erich Zenger, Das Buch Ruth (ZBAT 8; Zürich: Theologischer Verlag, 1992), 85, also uses the translation "Feldanteil," he continues to treat the purchase object as a whole piece of land as in "a farm" which had to "fall back" into the possession of someone, failing an heir. The question is: who becomes the new owner? 
An important inter-textual relation which can be kept in mind and also be tested against this background, is the history of the widow in $2 \mathrm{Kgs}$ 8:1-6 who appealed to the king for the return of her property after her long stay in the land of the Philistines. A close reading of v. 6 brings to light that the king ordered his official to return to her everything that belonged to her, including the "income" (NIV), that is the "proceeds" of the land, nota bene, not the land itself, although that is what she had asked for. The land probably belonged to her son in terms of the law of succession as set out in Deut 21. The stem of the word that is used here is (come in, bring in. The stem is recognisable in the Afrikaans equivalent: opbrengs and the English income).

Although multiple "gaps" for a modern readership had been left open by the author on a narratological level, the narratological context cannot be discussed in full here. The gaps which we are interested in are those left by the incomplete grammar in the text as well as around the seemingly unexplained and inexplicable legal actions performed within the text. Therefore it is indicated that the text be classified as a "legal text." 21

\section{RUTH 4:5 WITHIN THE CONTEXT OF THE ISRAELITE JURISPRUDENCE AND SOCIETY}

"Laws" regulating ownership of land can be found in Gen 13:11-12 and Lev 25:1-28 (all land in Israel belongs to God). Prescriptions around the "possession" of land are mentioned in Deut 26:1 and in Gen 15:3 where ירש is used for "taking possession" or "being heir." Texts dealing with "changing" of the existing laws of inheritance of the time, can be found in Num 27:1-11; Num

21 Although Robert L. Hubbard, The Book of Ruth (Grand Rapids: B. Eerdmans, 1988), 49, regards the book of Ruth as a piece of narrative literature in the first place and not as a legal treatise, it should be kept in mind that commentators and translators had struggled with Ruth 4:3-5 precisely because it contains a "legal text" which is inexplicable to us today. The summary of the legal inconsistencies as presented by Josiah Derby "The Problem of the Levirate Marriage," JBQ 19 (1990): 11-17, 15 is still valid, although the author may have considered his/her text to be completely intelligible within the sociocultural and religious frame of reference in which s/he was writing. Compare also Roland de Vaux, Oude Israel, 106; Gilles Gerleman, Ruth (BKAT 18; Neukirchen-Vluyn: Neukirchener Verlag, 1965), 9; Herman van den Brink, Bijbels Recht (Kampen: Kok, 1995), 145; Thomas Thompson and Dorothy Thompson, "Some Legal Problems in the Book of Ruth," VT 18 (1968): 79-99; Beattie, "Book of Ruth," 267; Tod Linafelt and Timothy K. Beal, Ruth and Esther (BerOl; Collegeville, Minn.: The Liturgical Press, 1999), 63-84; Katharine D. Sakenfeld, Ruth (IBC; Louisville, Kentucky: John Knox Press, 1999), 68-75; and more recent attempts by inter alia Gerda de Villiers, "Rut 3:9 en 4:5: Wat het die (leviraats) huwelik met lossing te doen?" HTS 68/1 (2012), Art. \#1278, 5 pages, DOI: 10.4102/hts.v68i1.1278. Davies, "Inheritance Rights," wrote a whole article in an attempt to justify the kinsman's change of mind. 
36:6-9; Josh 17:3-6 and Job 42:13-14. ${ }^{22}$ These texts deal with the inclusion of daughters alongside their brothers as heirs of their father's estate or in the absence of male heirs. This kind of inheritance was not unburdened. Hubbard ${ }^{23}$ points out that the sanction which followed this directive forbade a daughter who had inherited land to marry outside her father's tribe lest her property becomes part of another tribe's holding (Num 36:3) in which case it will be taken away from her. No mention is made, however, of the procedure or prescribed formalities whereby ownership of land should be conveyed onto the name of an heir.

In Ruth 4:5 the core action pivots around the sale of "a piece of land" or "a share in respect of land" (Ruth 4:3) by the widow of a deceased landowner contradictory to the prescription in Deut 21:15-17 which makes it clear that women did not inherit from their husbands. ${ }^{24}$ The sale mysteriously involves the peregrine daughter-in-law of the "seller" either by offering her as bride (as part and parcel of the sale) or by alleging that she is also selling the same piece of land. The mystery surrounding ownership of the land by the widow of the deceased can be cleared up by applying a simple legal concept which is called a usufruct. This presupposition will place Ruth in the same relationship to the land as Naomi would be, and the simultaneous sale by both women would make sense. They will become interchangeable in the context, and this is the solution that one could be in search of.

The challenge would be to ascertain to which extent the compilation represents a legal content. ${ }^{25}$ Investigation into the jurisprudence and customs of the time in which the narrative plays out is indicative in order to fill the many gaps left by the "corrupted" 26 grammar of the verse. ${ }^{27}$

22 Note that all these texts deal with female inheritance from the estates of a deceased father, whereas Deut 21 places a prohibition on wives' inheriting from the estates of their husbands. The texts only serve as confirmation that women could "own" land. Proverbs 31:16 re-iterates this fact: she was even allowed to "buy" land.

23 Hubbard, Ruth, 54.

24 Both Sakenfeld, Ruth, 71, and Gow, Book of Ruth, 254, have to yield that there is no indication in the Bible that women had in fact inherited from their husbands. Sakenfeld's attempt to fabricate a theory around "giving away" and then "retrieving" the land again, simply makes no sense. A woman could only sell what she owned.

25 Gow, "Ruth, Quoque a Coquette," 309 states that the term has legal significance and the elaboration ומאת רות "signifies that Ruth also has a legal interest in the transaction."

26 Gow, Book of Ruth, 161-162 and Gow, "Ruth, Quoque a Coquette," 311. In my opinion, the fact that this form needs "emendation" does not mean that it was "corrupted" ab initio. The author could have intended it to be ambiguous in order to include both widows. See Gow, Book of Ruth, 151.

27 "Back in the days of the Judges . .." Loader, Ruth, 22, thinks that this statement draws the reader's attention to the fact that the story plays out in a time when law was 
As Sakenfeld ${ }^{28}$ puts it: "So interlocked are the problems here, and so full of uncertainties, that the literature on the topic may fairly be described as chaotic."

Sakenfeld then notes that the "legal" issues at stake confuse the mind to such an extent that it can be overlooked that they actually fall in three categories namely customary, legal and moral. It is sometimes difficult to distinguish between the three kinds of "law" which were in use in ancient times. The belief is that a custom, if practiced over a long time, can become law. ${ }^{29}$ The difference between "law" and "custom" would be that "laws" would have a sanction attached to the transgression thereof, while non-compliance to a custom would generally not. Immoral conduct would, however, not easily go unpunished. The power and reaction of society to unsocial behaviour is probably immeasurable. $^{30}$

Only after a court case was finalised by the king and judgement was given, a rule was manifested. Ancient laws which governed everyday life were rather collections of the already existing customs and traditions of a people. ${ }^{31}$ Customs were unwritten behavioural codes. Because everybody knew them and lived by them, it was seldom necessary to spell them out or pen them down. ${ }^{32}$

practiced according to customary law. Linafelt and Beal, Ruth, 71, state that the author succeeded in convincing the reader that "some (contemporary) genuine custom" is referred to in Ruth 4:5.

28 Sakenfeld, Ruth, 70.

29 See René Vuilleumier, "Stellung und Bedeutung des Buches Ruth in alttestamentischen Kanon," TZ 44 (1988): 193-210, 187 on the topic of the levirate marriage: “...L'usage fait loit." A law can also be abolished through disuse. In South African Law the classical example can be found in the case of Green vs. Fitzgerald (1914 AD 88) which concluded that the law which defined adultery as a crime is no longer in use. See also Sakenfeld, Ruth, 69: our knowledge of customary proceedings of the time is "greatly lacking" obviously because they have either died out or were so commonly in use at the time that they did not need any explanation. For a contemporary definition of "Customary Law," see Francis Bosman and W. J. Hosten, Inleiding tot die Suid-Afrikaanse Reg en Regsleer (Durban: Butterworth, 1979), 8.

30 Although the scope of this article does not allow for a discussion on the ancient extra-biblical Jewish legislation and case laws, Milda Stanton, "Vroue-erfreg in die Ou Testament met die boek Rut as uitgangspunt," (M.A. dissertation, University of Pretoria, 2006) devoted a chapter which addressed research on this topic (including findings on the cuneiform laws and the laws of Hammurabi).

31 Thompson and Thompson, "Some Legal Problems," 83.

32 Raymond Westbrook, A History of Ancient Near Eastern Law (Leiden: Brill, 2003), 9, 14 is of the opinion that once the "laws" had been "frozen" into tablet form, they reflected society. They were meant as guidelines rather than to lie down binding rules. Russ Versteeg, Early Mesopotamian Law (Durham: Academic Press, 2000), 103 regards the Codex Hammurabi as common law recorded in writing whilst Carol E. Segal, "Studies of the Format and Usage in the Codex Hammurabi" (M.A. disser- 
This is probably the reason why some of the "legal" concepts known to the people in the narrative of Ruth were not explained but pre-supposed.

Green $^{33}$ acknowledges that "The understanding of the story's plot is heavily dependent on legal knowledge." She yields that "interpretations of legal matters and consequent application of conclusions to the story of Ruth are usually quite influenced by presuppositions often unexpressed and possibly unrecognised." She finds it a pity that such an attitude had not always been "fair" to the narrative itself, meaning that the text deserves more research on unclear matters in order to be understood. Unfortunately the author herself prefers not to take the trouble of tackling the legal uncertainties in the text but chooses to "interpret the story from the point of view of its own dramatic structures," thus offering no contribution to this important aspect of the narrative. The author is however correct when she comments that the uncertainty of how the expectations of law and custom can be met, adds to the tension in the story. ${ }^{34}$

\section{WHICH ARE THE MULTIPLE LEGAL PROBLEMS?}

Sakenfeld $^{35}$ recognises the main question as being the one concerning Naomi's right to sell Elimelech's land but like many other commentators, is also concerned about the way in which she acquired control over it. Van Wolde ${ }^{36}$ notes that the community as well as the narrator makes "one mother and one widow" out of Naomi and Ruth, both owning the same land, without explaining how they could own the same land.

In fact it is not really all the legal phenomena in the verse that are unknown, but mainly the mysterious "link" or "connection"37 (which seemingly connects some of them) which had not been named yet. In effect the main remaining questions are the following three:

(i) How does Naomi link with Ruth?

(ii) How does the levirate marriage link with the duty of redemption?

tation, Unisa, 1984), iii concludes that the Codex Hammurabi laws were ". . . amendments to an existing common law."

33 Barbara G. Green, "A Study of Field and Seed Symbolism in the Biblical Story of Ruth," (Ph.D dissertation, Graduate Theological Union, 1980), 70.

34 Green, "Study," 72.

35 Sakenfeld, Ruth, 70.

36 Ellen J. van Wolde, Aan de hand van Ruth (Kampen: Kok, 1993), 7.

37 Yochanan Muffs, Studies in the Aramaic legal papyri from Elephantine (Leiden: Brill, 2003), 169 calls it a "magical attachment." Gregory Goswell, "The Book of Ruth and the House of David," EvQ 86 (2014): 116-129, calls it an "intrinsic connection" and Thompson and Thompson, "Some Legal Problems," 85, a "legal fiction." The possibilities seem legion in literature on the topic. Through the ages and until today it is accepted that it was this "link" which convinced the next of kin to "give up his right of redemption" (Linafelt and Beal, Ruth, 69). 
(iii) How do these unnamed links "link" to female inheritance?

The possibility that ומאת רות represents this link had been researched without real usable outcome. In broad terms: how could Naomi sell the land, let alone Ruth?

\section{E A NAME FOR THE MISSING "LINK"}

It is easy to sense from the context that there must be "legal" applications which are inter-dependent or have common ground. ${ }^{38}$ It is suggested here that attempts to link the levirate marriage to the sale of land is the wrong starting point. The answer lies in one legal concept (or custom) which withstood the test of time to such an extent that it did not need to be called by name any more at the time when the narrative was written. ${ }^{39}$ It formed an integral part of Israel's everyday life and moral beliefs. One single "magical insight" can replace speculation around different concepts and unveil an unexpected solution. This tool emanates from the laws of inheritance and not from ancient procedures "connecting" and surrounding sale of land and marriage. This legal concept had gained a name during Roman times and is still in use: ${ }^{40}$ usufruct.

References to the possibility of this legal concept in the text, is scarce. Those who dared consider its existence in the problematic verse also did not follow their findings through. Davies ${ }^{41}$ begins his article by using the word $u s u$ fruct in the same breath as female inheritance of the land of the deceased hus-

38 Gow, "Ruth, Quoque a Coquette," 311: "Not only does Boaz link the redemption of the field with marriage to Ruth, he also gives the reason for making this link ... that she is the wife of the deceased." This is a clear example of a failed attempt to explain the "link." In fact this explanation does not clear up anything. No account is given of her right to sell the land. Compare other failed attempts by commentators like Thompson and Thompson, "Some Legal Problems"; Beattie, "Book of Ruth"; and Davies, "Inheritance Rights," who all devote whole articles to the matter but do not reach a satisfactory conclusion.

39 See Goswell, "Book of Ruth," 116-117, who acknowledges that the view that the book of Ruth is a "late" work (with its main purpose counteracting the reforms of Ezra and Nehemia) "continues to find many supporters" (Goswell, "Book of Ruth," 129), but appeals for the possibility that the book was written as a "continuity" and "delightful contrast" to the final chapters of Judges and whereas the book "looks for possible connections between the book and the house of David." These findings fall within the ideological context of the book though, an aspect which will not be discussed in full for purposes of this article.

40 Paul van Warmelo, 'n Inleiding tot die studie van die Romeinse Reg (Kaapstad: Balkema, 1965), 165, and Percival Gane, The Selective Voet: Being the Commentary on the Pandects (Paris ed. of 1829; 8 vols.; Durban: Butterworth, 1955), Book II, Title 1, 1-3, 312-313; Westbrook, History, 125 uses an example from the 6th Dynasty to point out that the concept of a usufructuary was already known in ancient Law, describing it as "one who eats but does not diminish."

41 Davies, "Inheritance Rights," 198. 
band, but one can either inherit the property or the usufruct. $^{42}$ The fact is, however, should she inherit the bare land, she would in any case own the proceeds thereof. No separate mention of inheritance of the usufruct would be needed. If she inherits the usufruct, it would mean that she did not inherit the land, but only the right to the proceeds. This and other attempts to force this legal concept onto the text are appreciated, but incorrect. Segal ${ }^{43}$ translates a law from the Codex Hammurabi (no. 180) which translation contains the word "usufruct." The word which was translated with "usufruct" in the original language is inaccessible to the author of this article, but the question can be asked whether the translator thereof understood the content of the term? The ultimate case where lack of insight shines through is Muffs ${ }^{44}$ who calls the right of the husband to administrate his wife's dowry, a usifruct (sic). Not only does Muffs confuse this legal term with a loan, but also calls the money "money of becoming a wife" which could not be further from the truth.

Sakenfeld $^{45}$ offers the possibility that Naomi could have been selling either the land or a usufruct thus admitting that a usufruct is a right in respect of land, that it can be sold, and that it has something to do with female inheritance. She even defines the right correctly in yielding that it means "the use of the land's produce." Reading on, it appears that the author does not understand the content of this legal concept or how to "link" it to the remaining questions. She still calls it "some claim." She is on the right track, but then surrenders the whole quest for an answer by saying: "we cannot reconstruct the inheritance regulations."

We can indeed reconstruct the inheritance regulations, by applying the law (as recorded in Deut 21) as well as the implied custom of the usufruct. Applying the usufruct to the situation in Ruth 4:5, will not only confirm that women did not inherit land from their husbands, but (recalling the abovementioned remaining questions) clear up the following:

- Naomi and Ruth both inherited the same right (each from her own deceased husband and in respect of the same piece of land) and are therefore interchangeable in the situation. Both are selling the same thing, one after the other.

- The levirate marriage and the right of redemption do not link, except maybe in a moral way. They both bestow a moral duty on a family member, and therefore lies on the same level. Both phenomena "link" with the underlying presupposition that the family (name and property) should be kept alive, but they remain different, independent actions.

42 As in the narrative written down in $2 \mathrm{Kgs}$ 8:1-6.

43 Segal, "Codex Hammurabi," 83.

44 Muffs, Studies, 164.

45 Sakenfeld, Ruth, 73. 
- Wives did not inherit from their husbands. They retained a right, which formed part of an ancient survival tool, and that is the right to use the proceeds of the bare dominium (house, land, money); Naomi acquired this right on the death of Elimelech and Ruth on the death of Mahlon, who inherited the land from Elimelech. The land lies without owner, but is still "in the family," awaiting the next rightful heir still to be born. ${ }^{46}$

The link that can connect all these possibilities is called a "usufruct."

So, Naomi (as well as Ruth) did not sell land but a usufruct in respect of that land, to which they both are (legally and customary) entitled. Now the חלקת : השדה They are not disposing of ownership to land, but of a lesser right: a "share (Anteil)" or "interest." This "magical attachment" is not confined to ancient custom, but still lives on to this day. 47

Why would the Law of the God of Israel prescribe that the wife of an Israelite man should be disinherited contrary to the core values of ancient Israel? A well-researched conclusion is given by Eskenazi: ${ }^{48}$ The land of Israel was divided and handed out to the people by God himself as part of the Covenant (Ezra 9:12b). The well-known belief was that implicitly God remained the owner thereof. Land could never completely fall into the hands of a private owner (Gen 49; Deut 6:10-15; 11:13-17; Lev 25: 55). The men were disobedient and married peregrine wives who worshipped pagan gods (Ezra 9 and 10, Neh 13:23-31) contrary to the commands of God. Suppose a man should die and leave his property (which includes land) to his peregrine wife and she subsequently marries a man from her own tribe, it would mean that she alienates God's property to a pagan god. As a preventative safety tool, she was never allowed to inherit from her husband.

The suggestion here is that she stayed entitled to the proceeds thereof as a means of survival, whilst the son/sons inherit the bare dominium. Should the ownership in respect of the land change, the position of the usufructuary will stay unchanged. It only lapses on the death of the holder thereof, but can also be disposed of or cancelled with her permission. It follows that Naomi did not

46 Irmtraud Fischer, "The Book of Ruth: A 'Feminist' Commentary to the Torah?" in Ruth and Esther: A Feminist Companion to the Bible (ed. Athalya Brenner; Sheffield: Academic Press, 1999), 24-49, 32, even goes as far as to allege that Ruth 4 entails the only instance where a baby was born "for a woman" (Naomi) and not "for him" as is usually the case in ancient terms. In these circumstances, the baby could just as well be born for Ruth herself, as she and Naomi stands in the same position regarding the land and the next of kin.

47 The difference would be that today it will be regarded as a personal right or servitude (thus legal) which has to be registered against the title deed of a landowner.

48 Tamara C. Eskenazi, "Out from the Shadows: Biblical Women in the Postexilic Era,” JSOT 54 (1992): 25-43, 35. 
lose her right in respect of the land when Mahlon (the owner after Elimelech) died, although Ruth (Mahlon's widow) was added as usufructuary in respect of the same property. The objective of such arrangement is clear: to provide for the surviving spouse(s).

\section{F DOES RUTH 4:5 IMPLY A LEVIRATE MARRIAGE?}

Through the ages, the marriage in the narrative of Ruth was regarded as a levirate one. ${ }^{49}$ Getting rid of this presupposition will also contribute to the easier and more understandable reading of Ruth 4:5. In the article of de Villiers ${ }^{50}$ we find yet another attempt to extend the duties of the redeemer to that of the levir, thus trying to enforce the duty of marrying the impoverished widow onto the person who buys the land. The author points out that both Frevel ${ }^{51}$ and Fischer ${ }^{52}$ admit that the conditions in the book of Ruth do not correspond with the requirements of the traditional levirate marriage, but still continue to allege that the book of Ruth cannot be separated from this law completely. ${ }^{53}$ De Villiers refers to Ruth 1:11-13 where Naomi has to admit to herself and to her daughters-in- law that a levirate marriage will not work in her case, but calls it a "direct pointer" towards the levirate marriage which will take place later in Ruth 4:5. Naomi's explanation in fact serves as confirmation to her daughtersin-law that the occurrence of a levirate marriage will be impossible. ${ }^{54}$ This does not mean that an ordinary traditional marriage would be excluded. ${ }^{55}$ An ordinary marriage would not deny them their inheritance and/or maintenance rights. No subsequent marriage could take away their status as ex-wives of the sons (heirs) of the deceased. If Boaz preferred to contract the duties similar to that of a levir onto himself, it does not mean that the marriage that takes place is a levirate one in the real sense of the word. Boaz's relationship to Ruth simply does not fit the definition. De Villiers further alleges that Boaz offers the duty

49 Diane Jacobson, "Redefining 'Family' in the Book of Ruth," WW 33 (2013): 5-11, 7, sees the dilemma which Naomi faces when trying to regard Orpa and Ruth as her family: "Naomi makes reference to the only- though clearly impossible- legal solution to their problem if they were her family: the system of levirate marriage ..."

50 De Villiers, "Rut 3:9," 1-5.

51 Christian Frevel, Das Buch Ruth (NSKAT 6; Stuttgart: Verlag Katholisches Bibelwerk GmbH, 1992), 108.

52 Fischer, "Ruth," 38.

53 De Villiers, "Rut 3:9," 4.

54 Ramona F. West, “Ruth: A Retelling of Genesis 38?” (Ph.D. thesis, Southern Baptist Theological Seminary, 1987), 11 also notes that Naomi's words in 1:11-13 may hint at the levirate institution, but it is "more than likely that Naomi is portraying the hopelessness of her situation as well as that of her daughters-in-law if they decide to go with her to Bethlehem."

55 J. Hardee Kennedy, Ruth (BBC 2; Nashville: Broadman, 1970), 480, offers one of the rare commentaries which gives support to this view by admitting that "there is at least the possibility that Boaz took Ruth to be his wife in the usual way of marriage, not by way of kinsman-redeemer only." 
to redeem and that of marriage to "Peloni Almoni" in the form of a package, "in order to maintain the name of the dead upon his inheritance." ment proves to be to the contrary. In order to provide an heir for Mahlon, only a marriage to his widow is necessary, he does not need to buy the land also. Boaz makes it sound the other way round. ${ }^{57}$ The author contradicts herself just in the following paragraph, when she admits that the redeemer in fact "has no responsibility in respect of Ruth." There is a difference between "taking responsibility" and "providing an heir." What is the main aim of the marriage which is to take place? The text supplies the "answer": "to maintain the name of the dead unto his inheritance."

The fringe benefit for Ruth to get married would be that she will be looked after now. Boaz does not take responsibility for her in respect of any duties as levir, but in accordance with his responsibilities as married man. ${ }^{58}$

\section{G KEEPING REDEMPTION AND THE LEVIRATE MARRIAGE APART}

Redemption takes place because Boaz is regarded as a close relative of Naomi and even of Ruth: ${ }^{59}$ This office qualifies him only in his capacity as possible redeemer. It includes Ruth as being "family" already. But a marriage between him and Ruth follows. Consequently the much needed descendant follows, regardless of whether Boaz was part of the extended family or not. Matthews ${ }^{60}$ supports Willis ${ }^{61}$ quoting the view that "Ruth's future becomes a consideration in the dealings only if the person who redeems Elimelech's land is a redeemer." A redeemer can improve the circumstances of an impoverished landowner by purchasing his/her land and providing a purchase price, but in order to provide

56 De Villiers, "Rut 3:9," 4.

57 See also Loader, Ruth, 79: "Boaz uses the question of the family property as an entrance to arrive at the case which is really at stake" (that is, the marriage to Ruth ${ }_{58}$ translation from the Dutch, M. de V-S.).

58 In the case of Boaz, we can even dare to say that his intention is not only to care (provide) for her, but he is also willing to "care" for her as in "love" (hesed). See also Kirsten Nielsen, Ruth: A Commentary (London: SCM Press, 1997), 31. The commentator regards the mutual love between God and human as an underlying theme in the book of Ruth.

59 Jacobson, "Redefining," 8, "It is noteworthy that Naomi also includes Ruth in this recognition, the operative word being 'our' (relative)" (Ruth 3:1-2).

60 Victor H. Matthews, Judges and Ruth (NCBC; Edinburgh: Cambridge University Press, 2004), 239.

${ }_{61}$ Timothy M. Willis, A Study of the Elders-Laws in Deuteronomy (Atlanta: SBL, 2001), 270. 
a legal heir for the land the groom does not need to be the purchaser or a member of the family. ${ }^{62}$

Boaz was clearly just the person who was prepared to fulfil both functions (analogous to what the God of Israel allegedly had already done for Ruth) namely that of redeemer as well as that of bridegroom (a providing husband). Ruth was already an established member of Elimelech's family and she could lawfully produce an heir. ${ }^{63}$ Neither Naomi nor Ruth was related by blood to Elimelech. They became family and took the same status on account of their marriages, regardless of their nationality. Naomi's relation to Elimelech's family is not questioned, so how is Ruth regarded as "alien" outside of the family? ${ }^{64}$ The ancestry of the heir is dependent on the mother, who is a member of the family already. ${ }^{65}$

\section{H CONCLUSION}

Taking the abovementioned into account, I would like to conclude with the result that it could never have been the intention of ancient Israelite man (or his God) to leave the widow unprovided for. To get married would be only one solution for her problem. God can provide either way he wants to, even by means of providing a (providing) husband. To sell whatever right she could

62 Herman J. Schilder, Richteren en Ruth: een vacature vervuld (Kampen: Kok, 1984), 59, offers the clearest and to my finding the most logical differentiation between the two rights and explains clearly why this marriage cannot be a levirate one. Roughly translated, he says that the law in Deut 25 should be interpreted in its narrowest sense: "a case of two brothers, sons of one father, who live together over and above all ... and this does not apply to Mahlon and Boaz. In the case of Boaz and Elimelech the degree of relatedness is even more remote."

63 According to Victor H. Matthews and Don Benjamin, Social world of Ancient Israel, 1250-587 B.C. (Peabody, Mass.: Hendrickson, 1995), 11, the father was responsible for electing a "legally" fit candidate for the marriage and to choose such candidate for the benefit of an already existing household (p. 13). This is probably what had happened already back in Moab when Ruth was approved of by Elimelech as future wife for his son.

64 Although Jennifer Koosed, Gleaning Ruth: A Biblical Heroine and her Afterlives (Columbia: University of South Carolina Press, 2011), 105, is of the opinion that Naomi, Ruth and Boaz decided to create their own (new) family, "and to define their own understanding of kinship and their responsibility to one another," this comment cannot be agreed upon. Although the added genealogy connected to Ruth 4:17 might give the impression that a new line of inheritance was created by the narrative and a new family had emanated, my contention is that one of the main aims of the book points towards the maintenance of an already existing family (Ruth 4:5). The genealogy was a later redactional addition aimed at verifying the house of David.

${ }^{65}$ Schilder, Richteren en Ruth, 59, sums up by saying that the reason why Boaz had "decided" to link the two actions, is simply that redemption of the land alone would change nothing for the family. 
have retained from the estate of her late husband even to a redeemer, would be the alternative waterproof solution thereto. These insights do not have as objective to convince the reader of an alternative translation merely on cultural or historical grounds. It serves only as optional filling for the open spaces still left after legal deconstruction ${ }^{66}$ and grammatical analysis of the text.

Let us conclude with Gow's ${ }^{67}$ insight: If it had not been for the pressure to find an object for the second (Gow meant the third) קנה in the sentence, it is doubtful that anyone would ever have thought of emending ומאת רות.

\section{BIBLIOGRAPHY}

Beattie, Derek R. G. "The Book of Ruth as Evidence for Israelite Legal Practice.” Vetus Testamentum 24 (1974): 251-267.

Bosman, Francis and W. J. Hosten. Inleiding tot die Suid-Afrikaanse Reg en Regsleer. Durban: Butterworth, 1979.

Botha, Phil J. "Answers Disguised as Questions: Rhetoric and Reasoning in Psalm 24." Old Testament Essays 22 (2009): 535-553.

Davies, Eryl W. "Inheritance Rights and the Hebrew Levirate Marriage: Part 1." Vetus Testamentum 31 (1981): 138-144.

Derby, Josiah. “The Problem of the Levirate Marriage." The Jewish Bible Quarterly 19 (1990): 11-17.

De Vaux, Roland. Hoe het oude Israel leefde. Utrecht: J.J. Romen, 1962.

De Villiers, Gerda. "Rut 3:9 en 4:5: Wat het die (leviraats) huwelik met lossing te doen?" HTS Teologiese Studies / Theological Studies 68/1 (2012), Art. \#1278, 5 pages. DOI: 10.4102/hts.v68i1.1278.

Efthimiadis, Helen. Meditating Opposites: Deconstruction and the Book of Ruth. M.A. dissertation, University of Port Elizabeth, 1991.

Eskenazi, Tamara C. "Out from the Shadows: Biblical Women in the Postexilic Era." Journal for the study of the Old Testament 54 (1992): 25-43.

Fischer, Irmtraud. "The Book of Ruth: A 'Feminist' Commentary to the Torah?" Pages 24-49 in Ruth and Esther: A Feminist Companion to the Bible. Edited by Athalya Brenner. Sheffield: Academic Press, 1999.

Frevel, Chrisitan. Das Buch Ruth. Neuer Stuttgart Kommentar, Altes Testament 6. Stuttgart: Verlag Katholisches Bibelwerk GmbH, 1992.

66 See Helen Efthimiadis, Mediating Opposites: Deconstruction and the Book of Ruth (M.A. dissertation, University of Port Elizabeth, 1991), 112-113: "The narrator could be aiming at a complete subversion of re-interpretation of Israelite social and legal institutions." This study deals with the technicalities of deconstruction as a whole, using the Book of Ruth as a vehicle because of its problematic legal texts which seem to be in need of deconstruction. I could, however, not agree with the author's following finding “. . . it is surely permissible and understandable that a woman could inherit property and fend for herself where the legal institutions which are meant to protect her were insufficient to do so." This statement results in speculation. In the book of Ruth the women did not inherit property and neither were they allowed to fend for themselves in public.

67 Gow, "Ruth, Quoque a Coquette," 309. 
Gane, Percival. The Selective Voet: Being the Commentary on the Pandects. Paris ed. of 1829.8 vols. Durban: Butterworth, 1955.

Gerleman, Gilles. Ruth. Biblischer Kommentar, Altes Testament 18. NeukirchenVluyn: Neukirchener Verlag, 1965.

Goswell, Gregory R. "The Book of Ruth and the House of David." Evangelical Quarterly 86 (2014): 116-129.

Gow, Murray D. "Ruth, Quoque a Coquette: Ruth 4:5." Tyndale Bulletin 41 (1990): 302-311.

. The Book of Ruth, its Structure, Theme and Purpose. Leicester: Apollos, 1992.

Green, Barbara G. "A Study of Field and Seed Symbolism in the Biblical Story of Ruth." Ph.D dissertation, Graduate Theological Union, 1980.

Hubbard, Robert L. The Book of Ruth. Grand Rapids: B. Eerdmans, 1988.

Jacobson, Diane. "Redefining 'Family' in the Book of Ruth." Word and World 33 (2013): 5-11.

Kautsch, Emil, ed. Gesenius' Hebrew Grammar. Translated by Arthur E. Cowley. Oxford: Clarendon, 1978.

Kennedy, J. Hardee. Ruth. The Broadman Bible Commentary 2. Nashville: Broadman, 1970.

Köhler, Ludwig and Walter Baumgartner. The Hebrew and Aramaic Lexicon of the Old Testament. Revised by Walter Baumgartner and Johann J. Stamm with assistance from Benedikt Hartmann, Ze'ev Ben-Hayyim, Eduard Y. Kutscher and Philippe Reymond. Translated and edited under the supervision of M. E. J. Richardson. Leiden: Koninklijke Brill, 1994-2000.

Koosed, Jennifer L. Gleaning Ruth: A Biblical Heroine and her Afterlives. Columbia: University of South Carolina Press, 2011.

Linafelt, Tod and Timothy K. Beal. Ruth and Esther. Berit Olam. Collegeville, Minn.: The Liturgical Press, 1999.

Loader, James Alfred. Ruth: Een practische Bijbelverklaring. Text en Toelichting. Kampen: Kok, 1994.

Matthews, Victor H. and Don C. Benjamin. Social World of Ancient Israel, 1250-587 B.C. Peabody, Mass.: Hendrickson, 1995.

Matthews, Victor H. Judges and Ruth. The New Cambridge Bible Commentary. Edinburgh: Cambridge University Press, 2004.

Muffs, Yochanan. Studies in the Aramaic Legal Papyri from Elephantine. Leiden: Brill, 2003.

Nielsen, Kirsten. Ruth: A Commentary. London: SCM Press, 1997.

Prinsloo, Willem S. Die boek Rut. Kaapstad: N.G. Kerkuitgewers, 1982.

Sakenfeld, Katharine D. Ruth. Interpretation: A Bible Commentary for Teaching and Preaching. Louisville, Kentucky: John Knox Press, 1999.

Sasson, Jack M. Ruth: A New Translation with a Philological Commentary and a Formalist-Folklorist Interpretation. Sheffield: JSOT Press, 1989.

Schilder, Herman J. Richteren en Ruth: een vacature vervuld. Kampen: Kok, 1984.

Segal, Carol E. "Studies of the Format and Usage in the Codex Hammurabi." M.A. Dissertation, Unisa, 1984.

Stanton, Milda. "Vroue-erfreg in die Ou Testament met die boek Rut as uitgangspunt." M.A. dissertation, University of Pretoria, 2006. 
Thompson, Thomas and Dorothy Thompson. "Some Legal Problems in the Book of Ruth." Vetus Testamentum 18 (1968): 79-99.

Van den Brink, Herman. Bijbels Recht. Kampen: Kok, 1995.

Van Leeuwen, Cornelis. Hosea. De Prediking van het Oude Testament. Nijkerk: Callenbach, 1968.

Van Warmelo, Paul. 'n Inleiding tot die studie van die Romeinse Reg. Kaapstad: Balkema, 1965.

Van Wolde, Ellen J. Aan de hand van Ruth. Kampen: Kok, 1993.

Versteeg, Russ. Early Mesopotamian Law. Durham: Academic Press, 2000.

Vuilleumier, René. "Stellung und Bedeutung des Buches Ruth in alttestamentischen Kanon." Theologische Zeitschrift 44 (1988): 193-210.

Waltke, Bruce C. and Michael P. O'Connor. An Introduction to Biblical Hebrew Syntax. Wynona Lake: Eisenbrauns, 1990.

West, Ramona F. “Ruth: A Retelling of Genesis 38?” Ph.D. thesis, Southern Baptist Theological Seminary, 1987.

Westbrook, Raymond. A History of Ancient Near Eastern Law. Leiden: Brill, 2003.

Willis, Timothy M. A Study of the Elders-Laws in Deuteronomy. Atlanta: SBL, 2001.

Zenger, Erich. Das Buch Ruth. Zürcher Bibelkommentare, Altes Testament 8. Zürich: Theologischer Verlag, 1992.

Dr. Milda de Vaal-Stanton, Department of Ancient Languages and Cultures, Faculty of Humanities, University of Pretoria. Email: mildas@mweb.co.za. 